\title{
Explicitáció és implicitáció az audiovizuális fordításban: a TED Talks feliratok elemzése
}

\author{
Malaczkov Szilvia \\ E-mail:malaczkov.szilvia@uni-bge.hu
}

\begin{abstract}
Kivonat: A nyelvészeti fordítástudomány egyik fő kutatási területe a fordítási univerzálék feltárása. Az eddigi vizsgálatok alapján ide tartozik az explicitáció jelensége is, amely, ha valóban fordítási univerzálé, akkor nyelvtől függetlenül minden fordítási irányban és szövegtípusban megtalálható. Ha ez a feltételezés igaz, akkor az explicitációnak az audiovizuális fordításában (AVF) is jelen kell lennie. Jelen tanulmányban az audiovizuális szövegek egyik típusán végzett eddigi és tervezett kutatásomat mutatom be. A kutatási korpuszt TED Talks elöadások önkéntes fordítók által magyar-angol és angol-magyar nyelvi irányban készített feliratai alkotják. A kétirányú vizsgálat végső célja az explicitáció mint lehetséges fordítási univerzálé igazolása az aszimmetria hipotézis segítségével. A tanulmány bemutatja a kutatáshoz szükséges elméleti hátteret, a kutatás alapjául szolgáló esettanulmányt és meghatározza a kutatás további irányát.
\end{abstract}

Kulcsszavak: explicitáció, implicitáció, aszimmetria hipotézis, audiovizuális fordítás, feliratozás, önkéntes fordítás

\section{Bevezetés}

Készülő disszertációmban a fordítástudomány keretein belül egy már régóta vizsgált jelenséget elemzek a fordítástudományi kutatások körében viszonylag új fordítástípuson belül. Az explicitáció és az explicitség mint a fordítás folyamatának és a fordított szövegeknek egyik fö jellegzetessége már régóta a nyelvészeti fordítástudományi kutatások középpontjában áll (Blum-Kulka 1986, Baker 1993, 1995). Az egyes kutatók szerint fordítási univerzálénak is tekinthető explicitáció jelenségét az eddig ebből a szempontból kevéssé kutatott audiovizuális fordításban (AVF) vizsgálom. A kutatási korpuszomat az önkéntes fordítók által magyar-angol és angol-magyar nyelvi irányban készített TED Talks feliratok alkotják. A kétirányú vizsgálat lehetővé teszi az explicitáció mint lehetséges fordítási univerzálé igazolását az aszimmetria hipotézis (Klaudy 2001a, 2001b, 2009b) segítségével.

Hivatkozás: Malaczkov Sz. 2020. Explicitáció és implicitáció az audiovizuális fordításban: a TED Talks feliratok elemzése. Fordítástudomány 22. évf. 1. szám. 46-68.

DOI: https://doi.org/10.35924/fordtud.22.1.4 
A kutatás elkezdésére a munkám során felmerült kérdések indítottak. Felsöoktatási intézmény oktatójaként többek között angol üzleti nyelvet tanítok a később gazdasági területen elhelyezkedő egyetemi hallgatóknak. A szemináriumi órákon az egyes gazdasági és üzleti témák mind szakmai mind nyelvi feldolgozásához sokszor használjuk az interneten ingyenesen és könnyen hozzáférhetö TED Talks előadásokat. A TED előadások elsődleges célja az, hogy ,,az elvont és bonyolult tudásanyagot mindenki számára érthetővé és elérhetővé tegye" (Anderson 2016: 287). A TED előadások didaktikai célú felhasználását elősegíti továbbá, hogy az angol nyelvü előadásokat önkéntes feliratozók más nyelvekre is lefordítják, így a haladó és kezdő nyelvtanulók számára is hasznosak. Felmerül azonban a kérdés, hogy a korlátozott felirathosszúság vajon mennyiben tudja lehetővé tenni a magyarázó jellegübb fordítást, melyhez inkább kifejtésre mint kihagyásra lenne szükség. Vajon az autentikus angol nyelvü előadásanyag és a fordított magyar feliratok nyelvi megformáltsága mennyiben befolyásolja a megértést, azaz hogyan őrződik meg vagy esetleg változik a jelentés a fordítás során?

Az egyetemen szakirányú továbbképzésben szakfordító- és tolmács hallgatóknak is tartok angol-magyar és magyar-angol irányú szakfordítás szemináriumokat. Az első féléves szemináriumi órák többek között az átváltási műveletekről, a fordítási megoldásokról és a fordítási stratégiákról is szólnak. Az explicitáció jelensége mint átfogó fordítási művelet (Klaudy 2003) is szerepel a fordítási kihívások megoldásainak tárgyalásánál. A harmadik féléves órákon az audiovizuális fordítással is megismerkednek a hallgatók, és ekkor felmerül az explicitáció és betoldás lehetőségének kérdése a feliratozásban, ellentétbe állítva a technikai korlátok miatt inkább megfigyelhető implicitáció és kihagyás jelenségével. Vajon a szaknyelvi, nem audiovizuális szövegeknél már megismert explicitációs illetve implicitációs stratégiákat ugyanúgy tudják alkalmazni a fordítók, vagy a müveletek típusai és gyakorisági arányaik is változnak?

Mivel a munkám során sokszor használtam az önkéntes fordítók által feliratozott TED Talks elöadásokat, valamint az általuk végzett munkát hasznosnak tartottam, magam is bekapcsolódtam az önkéntes feliratozásba. Belekezdtem az autentikus angol nyelvü TED Talks elöadások magyar feliratainak, valamint az autentikus magyar nyelvű előadások magyar átiratainak és angol fordításainak elkészítésébe. A feliratozás során beleláttam az önkéntes magyar TED fordítók munkájába és munkamenetébe is. A TED előadások önkéntes fordítása a részvételi kultúra részeként is értelmezhető (Pérez-González 2018, Pérez-González és Susam-Saraeva 2012, Glózer 2016, Király 2019). A nem professzionális fordításokban a fordítások minőségéért többek között a munkafolyamat is felelös, amelyben a lektoroknak fontos szerep jut. Az explicitáció kutatása hozzájárul az önkéntes fordítók és lektorok munkájához, így a fordítások minőségének biztosításához.

A kutatásra a munkám során megfigyelt kutatási ür indított, ugyanis az explicitáció/explicitség illetve implicitáció/implicitség jelenségét audiovizuális szövegekben az aszimmetria hipotézis segítségével még nem vizsgálták. A kutatás számomra azért releváns, mert a fordítástudományi doktori képzésben megszerzett 
elméleti tudást szeretném a gyakorlatban - az oktatásban és a feliratkészítésben - is alkalmazni, és a gyakorlatban megtapasztalt feliratozási kihívásokat pedig az elméleti háttér segítségével megoldani. Érdekes kérdést jelent továbbá, hogy a hivatásos fordítók munkájában megfigyelt jelenségek hogyan jelennek meg az önkéntes, azaz föként nem hivatásos fordítók munkájában.

Kutatásom célja feltárni, hogy az explicitáció és az implicitáció jelensége hogyan jelenik meg a feliratozás során, milyen explicitáció és implicitáció típusok jelennek meg és melyek a legjellemzőbbek. Ehhez a korábbi kontrasztív szövegnyelvészeti kutatásokat valamint az AVF jellegzetességei miatt a relevanciaelméletet veszem alapul. Célom továbbá, hogy a kutatási eredményeket a korábbi kutatások eredményeivel összevessem, és az audiovizuális fordításon belül további kutatási irányokat állapítsak meg.

A fordítástudomány keretein belül három fő kutatási terület biztosítja a vizsgálatom elméleti hátterét. Egyrészt az audiovizuális fordítással és ezen belül a feliratozással foglalkozó kutatások már elért elméleti eredményeire fogok támaszkodni. Másodsorban a nem hivatásos fordítók munkájának elemzésére, az önkéntes feliratozók munkafolyamatainak és fordítási stratégiáinak leírásaira. Harmadrészt pedig az explicitációs kutatások eddigi eredményeit fogom továbbfejleszteni kontrasztív szövegnyelvészeti és relevanciaelméleti szemszögböl. Az elméleti részben ezeket a kutatási területeket mutatom be, főként arra fókuszálva, hogy feltárjam a kutatási ürt, melyet a jelen doktori kutatásommal kívánok betölteni. Ez az űr pedig az explicitáció jelenségének kutatása az audiovizuális fordításban az aszimmetria hipotézis segítségével. A gyakorlati részben egy esettanulmányt ismertetek, majd kijelölöm a kutatás további irányát.

\section{Az audiovizuális fordítás a fordítástudományban}

\subsection{Az audiovizuális fordulat}

Az audiovizuális fordítás megjelenése szoros kapcsolatban áll a filmipar kialakulásával és fejlődésével. Az 1920-as években megjelentek az első, már feliratokat tartalmazó némafilmek. A filmek külföldi terjesztése szükségessé tette a feliratok, később pedig a hangzó szövegek fordítását. Gottlieb (1992) szerint a feliratozást kezdetben úgy jellemezték, mint a „szükséges rossz”.

Az első filmfordítással kapcsolatos írások az 1960-as években jelentek meg. Az audiovizuális fordítás szakmai elismertségéhez a fordítástudományon belül nagyban hozzájárult Katharina Reiss szövegtípusokról írt 1971-es monográfiája. A kezdeti három szövegtípus (informatív, expresszív, operatív) mellé Reiss bevezetett egy negyediket is, melynek az audiomediális nevet adta. Az audiomediális szövegek mindhárom másik szövegtípust magukban foglalhatják, és jelentősen eltérnek a többi szövegtípustól két szempontból is: egyrészt függnek a nem nyelvi, azaz a technikai tényezőktől (magától a médiumtól), valamint a verbális mellett a 
vizuális, az akusztikus és a grafikus elemektől is. Reiss tehát már akkor felismerte és leírta az audiovizuális szövegek két fö jellegzetességét, melyek a mai elnevezésben a multimodalitás és a technikai korlátozottság.

A kezdeti audiovizuális kutatások során felállították a feliratozás első hibatipológiáját (Dollerup 1974), vizsgálták a szinkronszövegek szájmozgásra igazítását (Fodor 1976, idézi Chaume 2002), valamint leírták a korlátozott fordítási környezet jellemzőit is (Titford 1982, Mayoral 1988). Ezek a kutatások indították el az 1990es években az audiovizuális fordítással kapcsolatos széleskörü kutatást.

Az audiovizuális fordítás az 1990 és 2010 közötti években a fordítástudományi kutatások perifériájáról a középpontba került. A feliratozás bekerült az egyetemi oktatásba (Gottlieb 1992), és a kutatásokat az első mozgókép megjelenésének centenáriumi ünnepsége (1995) is felerősítette. Mivel ez az időszak egybeesett a modern technológiai fejlődés elindulásával is, joggal mondhatjuk, hogy a 21. század elhozta az audiovizuális fordulatot a fordítástudományi kutatásokban (Remael 2010, Chaume 2013). Az AVF autonóm kutatási területté (autonomous discipline) vált a fordítástudományon belül, melynek már kialakultak a saját kutatási modelljei, és így elszakadhatott az általános, azaz nem audiovizuális fordítások kutatására leginkább használt szövegelemzési modellektől, másrészt viszont még az interdiszciplinaritás erősen jellemző erre a kutatási területre (Romero Fresco 2012).

2018-ra az AVF már teljesen kiforrt, önálló kutatási területté vált a fordítástudományon belül (Chaume 2018, Zanotti-Ranzato 2019). Ez az érett tudományág (mature discipline) magától a fordítástudománytól kölcsönöz kutatási irányokat, így az interdiszciplinaritás mellett az intradiszciplinaritás is jellemzi. Chaume (2018) szerint az AVF-et eddig négy fordulat jellemezte: a leíró, a kulturális, a szociológiai és a kognitív fordulat. Az AVF ezekben az időszakokban többször is újradefiniálta önmagát, és szélesítette a határait, befogadva a videójáték lokalizációt, a transzkreációt vagy a nem hivatásos feliratozást és szinkronizálást is (nonprofessional subtitling and dubbing). Ezek az új formák pedig új AVF modellek felállításához vezettek.

Szarkowska (2018) egy újonnan induló csak audiovizuális fordítással foglalkozó folyóirat, a Journal of Audiovisual Translation első számában az AVF jelenlegi kutatási területeit szedi csokorba. Az audiovizuális fordítás felhasználja a már meglévő fordítástudományi elméleteket a saját kutatásában, de már olyan kutatási területek is megjelennek, amelyek inkább jellemzők erre a területre. Szarkowska számos lehetséges kutatási irányt sorol fel az AVF-en belül: recepcióelmélet és a fordítási folyamat kutatása (TRP/translation process research), a média akadálymentesítése (media accessibility), minőségbiztosítás, gépi fordítás, nem hivatásos fordítás (rajongói és közösségi közremüködésen alapuló fordítás/fan translation and crowdsourcing), az AVF története, genderkutatás, többnyelvüség, AVF korpuszok, ideológia, manipuláció és cenzúra, audiovizuális fordítóképzés, AVF és nyelvtanulás.

Az AVF-re jellemző kutatási területek talán legátfogóbb leírását Holmes (1972) nyomán Di Giovanni és Gambier (2018) készítette el (1. ábra). A négy fő kutatási 
terület különböző kutatási megközelítéseket és ezekhez tartozó különböző kutatási módszereket jelöl.

Az 1. ábra, mely az AVF kutatási területeit összegzi, egyértelmüen bizonyítja, hogy az AVF ugyanúgy létjogosultságot nyert a fordítástudományi kutatásokban, mint korábban maga a fordítástudomány a többi kutatási terület mellett.

Doktori kutatásom az AVF kutatási területeinek mind a négy ágához illeszkedik. Az explicitáció jelenségét a leíró fordítástudományi paradigmán belül vizsgálom egy olyan önkéntes fordítói csoport munkájában, amelynek célja a tudományos-ismeretterjesztő anyagok széleskörü nyelvi hozzáférhetőségének biztosítása. Az eredményeket a fordítóképzésben is szeretném majd felhasználni, így az alkalmazott kutatások körébe is tartozik. Végül, habár a kutatás szorosan nem a nyelvpolitika témakörébe tartozik, de egy szükebb körben elterjedt lingvakultúra, a magyar nyelv jellegzetességeinek vizsgálatával foglalkozik.

\section{1. ábra}

Az AVF kutatási térképe (Di Giovanni és Gambier 2018 nyomán)

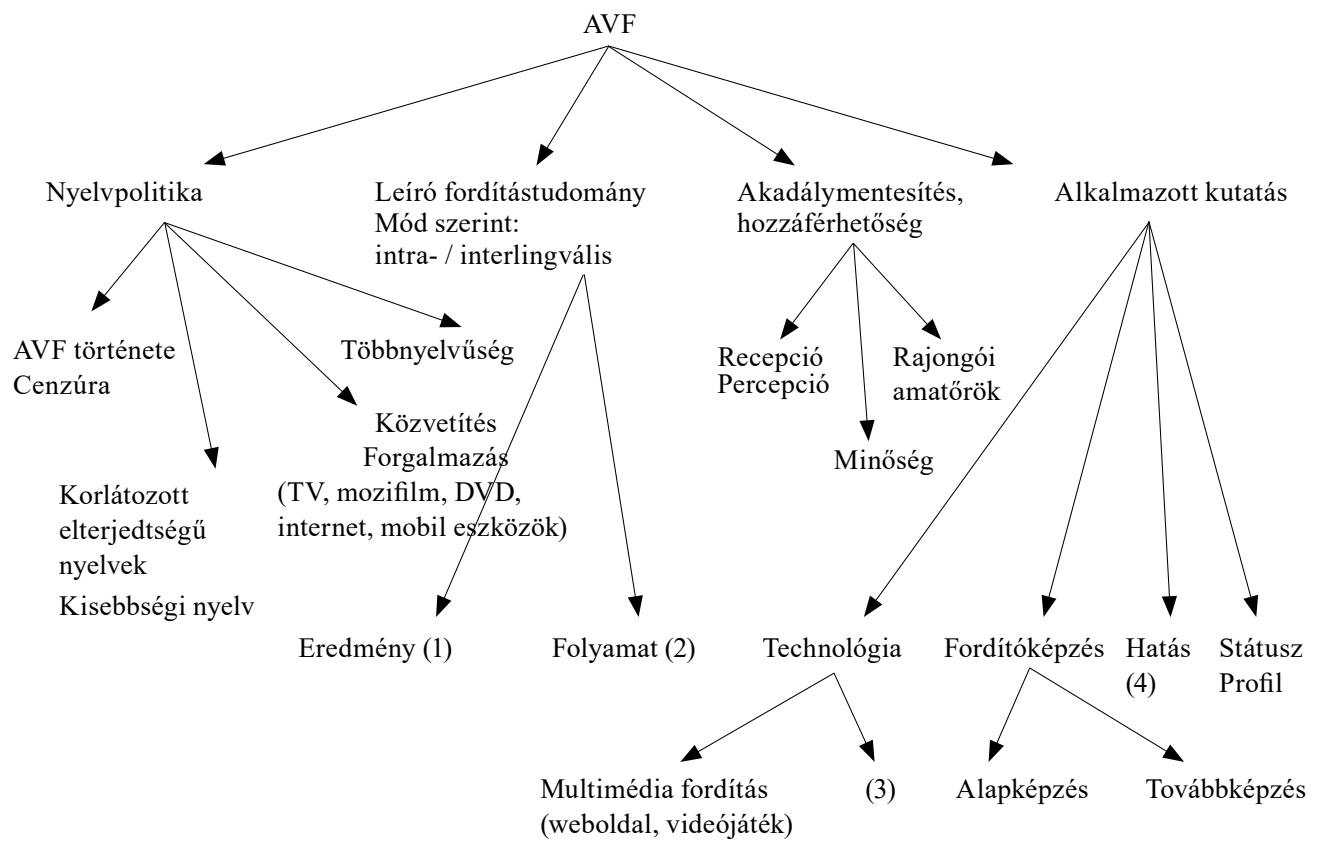

\subsection{Az audiovizuális szöveg}

Az audiovizuális fordítás ugyanúgy kereste sokáig a helyét a fordítástudományon belül, mint maga a fordítástudomány a többi tudományágon belül. Hatim és Mason (1997) a fordítók világát a dichotómiák világaként jellemzi, amelyben a fordítási módok dichotómiája például az írásbeli és a szóbeli fordításra különül el. Három 
fordítástípust különítenek el: az írásbelit, a szóbelit (tolmácsolás) és a szóbeliről írásbelire (feliratozás) fordítást.

Klaudy Kinga (1999b: 27) is ezt a felosztást követi fordításelméleti definíciójában. Fordításon a fordítás összes fajtáját érti, tehát ez a korábbi fordítástudományi elméletektől eltérö tág és megengedő definíció már célul tüzi ki a fordítás kiterjesztését akár az audiovizuális szövegekre is. Négyféle fordítástípust különböztet meg a szóbeliség és írásbeliség dichotómiájára építve: 1. írott szöveg írásbeli fordítása, 2. írott szöveg szóbeli fordítása (blattolás), 3. hangzó szöveg szóbeli fordítása (tolmácsolás), 4. hangzó szöveg írásbeli fordítása. Az audiovizuális fordítástípuson belül a szinkronizálás a harmadik kategóriába eshet (hangzó szöveg szóbeli fordítása), míg a feliratozás a negyedik kategóriába (hangzó szöveg írásbeli fordítása). Az AVF tehát még nem alkot külön kategóriát, hanem azokkal a hagyományosabbnak tekinthetö fordítástípusokkal kerülnek egy csoportba az egyes típusok, amelyekkel hasonlóságot mutatnak fordítási mód szempontjából.

Chaume (2002) már teljesen elkülöníti az audiovizuális fordítást az írásbeli vagy szóbeli fordítástól. Az audiovizuális fordítást nem csak egyfajta szövegtípusnak tekinti a jogi, müszaki vagy természettudományos fordítás mellett, hanem a fordítás egy új módjának, amelyben megjelenhetnek jogi, müszaki vagy akár természettudományos szövegek is. Chaume (2002) az audiovizuális szöveg (audiovisual text) kifejezést használja, melybe bármely szövegtípus beletartozhat, legyen az akár tartalom-, forma- vagy felhívásközpontú. Pérez González (2008: 13) szintén az audiovizuális szöveg (audiovisual text) terminust használja. Definíciója szerint az audiovizuális fordítás ,a fordítástudomány egy ága, mely a multimodális és multimedális szövegek átültetésével foglalkozik egyik nyelvről és kultúráról egy másikra".

A forrásnyelvi szöveg audiovizuális fordítás esetén inkább forrásanyagnak tekinthető, mint pusztán szövegnek, hiszen a nyelvi jelek - írott (vizuális) és hangzó (auditív) szöveg - mellett a paralingvisztikai (nonverbális) jelek is beletartoznak. Az audiovizuális szövegek általában abban térnek el a hagyományos, nyomtatott szövegektől, hogy két különböző jelrendszert és két különböző kommunikációs csatornát használnak (Gambier 2012, Remael 2010). Így megkülönböztetünk audió-verbális jeleket (a hangzó szöveg), audió-nonverbális jeleket (minden más hanghatás), vizuális-verbális jeleket (írott szöveg) és vizuális-nonverbális jeleket (minden más látható jel). Ezeknek a különböző jelrendszereknek az összhatása adja ki a végső audiovizuális szöveget, amely sokkal komplexebb, mint egyes részeinek az összessége.

Zabalbeascoa (2008) ezeknek a különböző jelrendszereknek az audiovizuális szövegben betöltött szerepe és jelentősége alapján különböző audiovizuális szövegtípusokat különböztet meg. Vannak olyan AV szövegek, melyekben nagyobb szerep jut a verbális elemeknek, míg másokban a nonverbális elemeknek, illetve bizonyos szövegek inkább hangzó anyagot tartalmaznak, míg másokban a vizuális, azaz írott anyagok is fontos szerephez jutnak. Ennek alapján az audiovizuális szövegeket egy tengelyekkel ábrázolt skálán lehet elhelyezni. Az audiovizuális szövegek kutatása- 
kor így jelentősége lesz a kutatott AV szövegtípusnak vagy müfajnak is, ezért a különbözö AV müfajok közötti összehasonlító kutatásokra is szükség lehet.

2. ábra

Az audiovizuális szövegek multimodális skálája Zabalbeascoa (2008) alapján

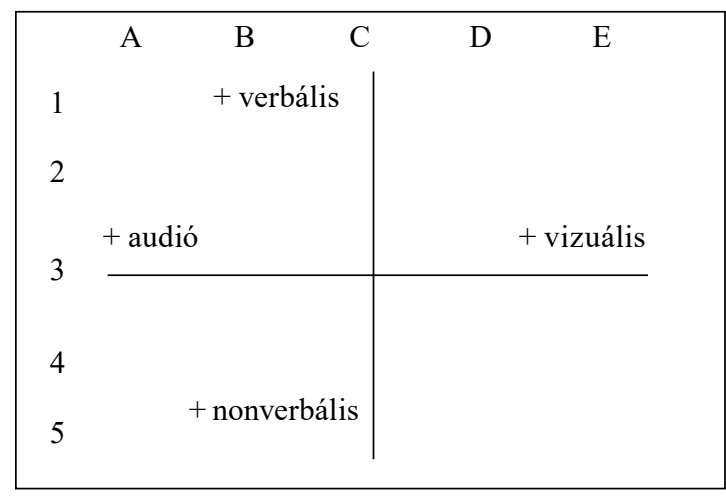

A fenti ábra szemléletesen mutatja, hogy a multimodális anyagok esetén a verbális nyelvi elemeket nem önmagukban, hanem az audiovizuális anyagban megjelenő többi elemmel összhangban kell vizsgálni. Az audiovizuális szövegek kutatásakor tehát nem hagyhatjuk figyelmen kívül a médiumspecifikus tényezőket sem.

\subsection{A feliratok típusai}

A feliratozás tekinthető az audiovizuális fordítás legkorábban megjelent típusának, hiszen az első némafilm fordítások feliratokat tartalmaztak (Shuttleworth és Cowie 1997/2014, Baker 1998). A később megjelent főbb audiovizuális fordítási módok a feliratozás mellett a szinkonizálás és a hangalámondás volt. Ezeket hívják az AVF triádjának (Bogucki 2010). Azonban a legújabb fordítási módokat is figyelembe vevő csoportosítás alapján a három fó AVF mód a feliratozás, a revoicing és az AVF kisegítő formái (assistive forms of AVT) (Pérez-González 2014). A revoicing a hangzó nyelvi transzfer különböző fajtáit tartalmazza, pl. szinkronizálás, hangalámondás, narráció. Az AVF kisegítő formái az információhoz való hozzáférést segítik elő az érzékszervi korlátozottsággal élők számára (audiónarráció, a siketek és nagyothallók számára készített feliratok, respeaking). Az audiovizuális fordítás típusai azonban nem statikusak, hanem dinamikusan változnak. Ilyen újonnan megjelenő fordítástípus például az audiófeliratozás (AST - audio subtitling) (Orero és Braun 2010).

A feliratozáson belül is számos típust különböztethetünk meg, és ezek a típusok dinamikusan változnak a technológiai és a befogadói igények alapján. A legalapvetőbb különbség az intralingvális és interlingvális feliratok között van. Az intralingvális feliratokat újrafogalmazásnak (rewording) is nevezik. Ebben az eset- 
ben a feliratok az eredetivel azonos nyelven készülnek el a siketek és nagyothallók vagy a nyelvtanulók számára, de akár az önkéntes fordítók munkájának megkönynyítésére is. Az interlingvális feliratok az eredetitől különböző nyelven íródnak, és céljuk az információhoz való hozzájutás elősegítése az adott nyelvet nem vagy nem jól beszélő nagyközönség számára. A Perego (2003) által készített, az intralingvális és interlingvális feliratozás jellemzőit tartalmazó táblázatot a TED Talks feliratozások során használt jellemzőkkel egészítettem ki (dőlt betűs rész a 3. és 4. táblázatban).

1. táblázat

Az intralingvális feliratozás típusai Perego (2003) alapján

\begin{tabular}{|l|l|l|l|}
\hline & \multicolumn{3}{|c|}{ Intralingvális feliratozás } \\
\hline Definíció & \multicolumn{2}{|c|}{ Feliratok az eredetivel azonos nyelven (FNy = CNy) } \\
\hline Címzettek & $\begin{array}{l}\text { Siketek és } \\
\text { hallássérültek }\end{array}$ & Nyelvtanulók & Önkéntes fordítók \\
\hline Jellemzők & $\begin{array}{l}\text { Az eredeti dialógus } \\
\text { irott és egyszerüsített } \\
\text { átirata }\end{array}$ & $\begin{array}{l}\text { Az eredeti dialógus } \\
\text { vágatlan és azonos } \\
\text { idejü átirata }\end{array}$ & $\begin{array}{l}\text { Az eredeti dialógus } \\
\text { szinte vágatlan, } \\
\text { azonos idejü átirata }\end{array}$ \\
\hline Funkció & $\begin{array}{l}\text { Fő vagy kisegítő } \\
\text { eszköz az } \\
\text { audio(vizuális) } \\
\text { információ eléréséhez }\end{array}$ & $\begin{array}{l}\text { Támogató megoldás } \\
\text { különféle } \\
\text { nyelvtanulási } \\
\text { kontextusban }\end{array}$ & $\begin{array}{l}\text { Támogató eszköz az } \\
\text { eredeti } \\
\text { audio(vizuális) } \\
\text { információ eléréséhez }\end{array}$ \\
\hline
\end{tabular}

2. táblázat

Az interlingvális feliratozás típusai Perego (2003) alapján

\begin{tabular}{|l|l|l|l|}
\hline \multirow{2}{*}{ Definíció } & \multicolumn{3}{|c|}{ Interlingvális feliratozás } \\
\hline Címzettek & Halló célközönség & Nyelvtanulók & Nagyközönség \\
\hline Jellemzők & $\begin{array}{l}\text { Normál: } \\
\text { Filmdialógus eredeti } \\
\text { nyelven (L2), felirat } \\
\text { célnyelven (L1) }\end{array}$ & $\begin{array}{l}\text { Fordított: } \\
\text { Filmdialógus } \\
\text { célnyelven (L1), } \\
\text { felirat eredeti nyelven } \\
\text { (L2) }\end{array}$ & $\begin{array}{l}\text { Kevert: } \\
\text { Elöadás eredeti } \\
\text { nyelven (L2), felirat } \\
\text { eredeti (L2) vagy } \\
\text { célnyelven (L1) }\end{array}$ \\
\hline Funkció & $\begin{array}{l}\text { Írott eszköz a külföldi } \\
\text { filmek megértéséhez } \\
\text { a FNy-i dialógusok } \\
\text { reprodukciója és } \\
\text { adaptációja révén }\end{array}$ & $\begin{array}{l}\text { Elósegíteni a külföldi } \\
\text { szókincs (esetleges) } \\
\text { elsajátítását }\end{array}$ & $\begin{array}{l}\text { Fö vagy támogató } \\
\text { megoldás az eredeti } \\
\text { audio(vizuális) } \\
\text { információ }\end{array}$ \\
megértéséhez
\end{tabular}


Az intralingvális és interlingvális feliratok mellett idővel megjelent egy újabb felirattípus is: a bilingvális (Pérez González 2008). A bilingvális vagy kétnyelvű feliratokat olyan közösségek számára készített audiovizuális anyagoknál használják, ahol az adott közösségben két nyelv szorosan egymás mellett él.

Emellett Gottlieb (1998) megkülönböztet nyílt és zárt feliratokat is. Ezek nem nyelvi, hanem technikai különbségeket hordoznak. A nyílt feliratok kötelezően megjelennek a képernyőn, és ez jellemző a moziban megjelenő feliratos filmekre vagy a felirattal sugárzott televíziós müsorokra. A zárt feliratok választhatók, azaz teletext formájában elérhetők, amennyiben a televíziómüsor célközönsége igényt tart rá. A TED felirat a zárt feliratok közé tartozik.

A legújabb felirattípusokra Díaz-Cintas (2018) bevezette a kiberfelirat (cybersubtitle) terminust, mely az interneten található különböző felirattípusok összefoglaló neve. Két fö fajtája az önkéntes feliratok és a közösségi közremüködésen alapuló feliratok. Ezek a feliratok lehetnek rajongói feliratok, gerilla feliratok és altruisztikus feliratok. Továbbá megkülönböztethetjük az álfeliratokat és a valódi feliratokat.

\section{3. ábra}

A kiberfeliratok típusai Díaz-Cintas (2018: 133) alapján

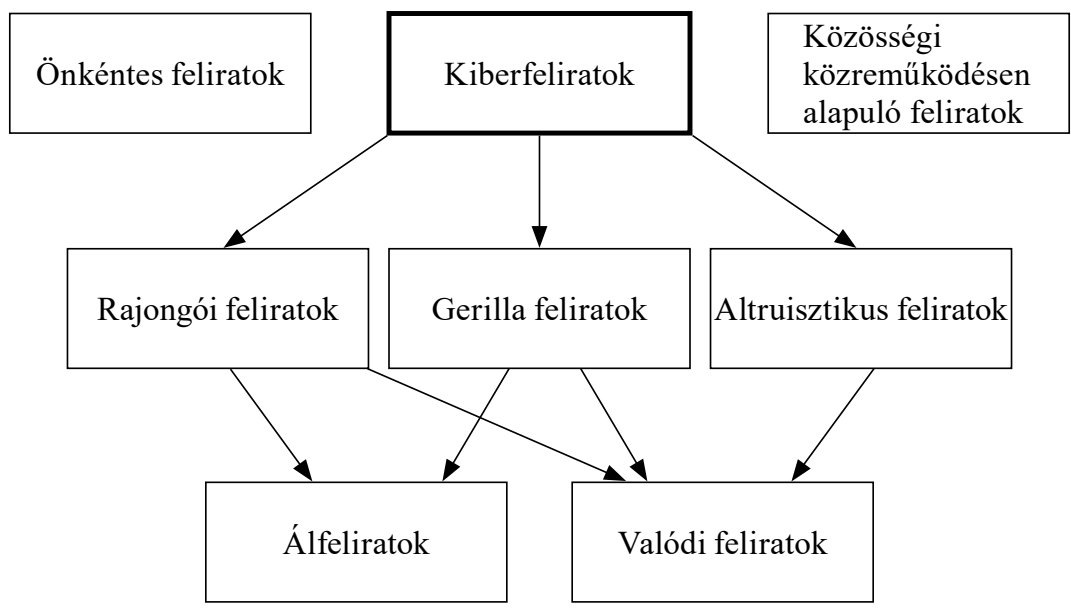

A TED feliratozás a közösségi közremüködésen alapuló feliratok közé tartozik, hiszen a TED alapítvány biztosítja a feliratozáshoz szükséges hátteret. Ezek a feliratok altruisztikus célból jönnek létre, azaz az önkéntes fordítók azért készítik el a feliratokat, hogy a TED előadásokat azok is megértsék, akik nem beszélik az adott előadás nyelvét. A TED feliratok ezenkívül a valódi feliratok közé tartoznak, azaz nyelvezetükben hủek az előadás szövegéhez. Ezek a jellemzők a fordításkutatás szempontjából relevánsak, mivel az audiovizuális modalitások közül ebben a felirattípusban a nyelvi dimenzió a legfontosabb. A TED interlingvális feliratok egy adott sablon alapján készülnek az Amara szoftverben. A sablon már tartalmaz- 
za az időzítéssel (timing) ellátott mesterfeliratot, azaz a forrásnyelvi feliratot, amely alapján a fordítók dolgoznak.

$\mathrm{Az}$ itt ismertetett felirattipológia is mutatja, hogy a feliratokra vonatkozó kutatások adott felirattípusokra lehetnek csak érvényesek, és alkalmazhatóságuk más felirattípusokra további kutatásokat tesznek szükségessé.

\section{A nem hivatásos fordítók}

A nem hivatásos fordítók nem tekinthetők egy homogén csoportnak, hiszen többféle fordítócsoportot is érthetünk alatta: a nyelvtanulókat, a családtagok számára nyelvi közvetítőként funkcionáló gyermekeket, vagy éppen az önkéntes feliratozókat (Paksy 2016, Horváth 2015, Antonini et al 2017, Zimányi 2017).

A digitális technológia fejlődése, a feliratozási szoftverek ingyenes és emiatt széleskörü elterjedése lehetővé tette a fordítási folyamatban való részvételt azok számára is, akik formális fordítóképzésben nem vettek részt, viszont egyéni érdeklődésből vagy altruisztikus megfontolásból szívesen vállalták fel fizetés nélkül a mások által készített audiovizuális anyagok feliratozását. Az önkéntes fordítók megjelenése a fordítási folyamatban kezdetben felzúdulást váltott ki a fordítási szakmában és a fordításkutatásban is, hiszen a hivatásos fordítók féltették tőlük a megélhetésüket és a szakma felhígulását látták a munkájukban, a kutatók pedig elemzésük tárgyának sokáig csak a képzett fordítók munkáját tekintették (PérezGonzález és Susam-Saraeva 2012, Antonini et al 2017, Orrego-Carmona és Lee 2017).

A 21. század első évtizedében azonban már a kedélyek lecsillapodtak, hiszen az önkéntes fordítók bizonyos csoportjai olyan munkát folytatnak, amelyért anyagi ellenszolgáltatást sem a jelenben sem a jövőben nem fizetnének gazdasági okokból a cégek, valamint a fordítástudomány is befogadta berkeibe ezt a megállíthatatlanul növekvő fordítási módot.

A nem hivatásos fordítók tevékenységének kutatása egyrészt beilleszthető az eddigi hagyományos fordítástudományi kutatások paradigmáiba, és ezáltal a fordítók egy új csoportján tesztelhetők az eddig felállított kutatási hipotézisek és elméletek. Ilyen kutatási terület lehet a fordított szövegekre jellemző tulajdonságok vizsgálata az önkéntes fordítók munkáiban is. Az explicitációkutatással kapcsolatban Blum-Kulka (1986) már megfogalmazta azt a kutatási igényt, hogy az adott hipotézist minél több fordítástípusban és minél többféle fordító munkájában lenne érdemes vizsgálni, hogy bebizonyosodjon, vajon tényleg a fordításra jellemző általános tulajdonságról van-e szó.

Az önkéntes feliratozásnak két típusát különíti el Jiménez-Crespo (2017): a webalapú együttműködő fordítások (online collaborative translation) közé tartoznak a rajongói fordítások, míg a közösségi közreműködésen alapuló fordítások (translation crowdsourcing) közé a vállalatok által kezdeményezett közösségi fordítások, mint például a TED, a Facebook vagy a Wikipedia fordítások. 
Jiménez-Crespo (2017) az online önkéntes fordítást a fordítástudomány föbb kutatási területei mentén vizsgálja: kognitív fordítástudomány, a fordítás minőségével kapcsolatos kutatások, szövegnyelvészet, AVF és normakutatás, szociológia és fordítóképzés. Véleménye szerint ezen kutatási területek mindegyike vizsgálható az online önkéntes fordításokban is: a fordítás folyamata a közösségi közremüködésen alapuló modellekben, a fordítók motivációja, a célnak megfelelö ( fit for purpose) minőség vagy akár a feliratozó platformok hatása a fordítási folyamatra. Külön kiemeli a korpuszalapú fordításkutatáson belül a fordított szövegekre jellemző általános tulajdonságok vizsgálatát ebben a fordítástípusban. A jövőre nézve azonban nem tudja megjósolni, hogy milyen kutatási területek alakulnak majd ki ebben a dinamikusan változó fordítástípusban mint az online önkéntes fordítás.

\section{Explicitáció és explicitség a fordítástudományban}

Számos kutató vizsgálja a fordított szövegekre jellemző és fordítási univerzáléknak is tekintett nyelvi elemek megjelenését a különbözö szövegtípusokban. Baker (1993) szerint ilyen univerzálé a célnyelvi szövegek explicitségi szintjének növekedése a forrásnyelvi szöveghez és az eredeti célnyelven írt szövegekhez viszonyítva. Az explicitáció széleskörü kutatását Blum-Kulka (1986) explicitációs hipotézise indította el. A hipotézis szerint a fordított szövegek az explicit kohéziós elemek szintjén eltolódást mutathatnak az eredeti forrásnyelvi szövegekhez képest. Az explicitációt már fordítási univerzálénak tekintette, mivel függetlenül a fordító személyétől - legyen professzionális vagy nem professzionális fordító - a fordítási folyamatban megjelenik. Ennek bizonyítására azonban felhívja cikkében a figyelmet az empirikus kutatások folytatásának szükségességére.

Az explicitációnak számos definíciója létezik. Klaudy Kinga (1999a: 5) definíciója szerint ,az explicitáció olyan fordítási művelet, amelynek során a fordító nyíltabban, világosabban, esetleg több szóval fejez ki valamit a célnyelvi szövegben, mint ahogy azt a forrásnyelvi szöveg szerzöje tette”. Pápai Vilma (2001: 39) részletes definíciója alapján az explicitáció lehet tudatosan választott vagy ösztönösen végrehajtott változtatás a fordítás során. Ezek szerint a fordítási stratégiák elméleti ismerete nélkül is végrehajtják ezt a típusú változtatást a fordítók. A definícióban az explicitáció célja is megfogalmazódik: „a fordító a célnyelvi szövegben - a könnyebb/biztosabb értelmezés elösegítésére - kifejt/felszínre hoz bizonyos, az eredetiben nem kifejtetten [...] meglevő nyelvi vagy nyelven kívüli információt". Így a lingvisztikai elemek mellett a paralingvisztikai és kinezikus elemek is az explicitációs kutatások részét képezhetik.

Az explicitációnak számos tipológiája is létezik (Heltai 2005, 2014, Pápai 2004, Klaudy 1993, 1999, Perego 2003). Klaudy Kinga (1999: 5-10, 2009a) az explicitáció négy típusát különbözteti meg: kötelező, fakultatív, pragmatikai és fordításspecifikus explicitáció. A fakultatív explicitáció a nyelvhasználati különbsé- 
gekkel magyarázható és történhet szószinten, mondatszinten és szövegszinten is. Klaudy szerint ezek a müveletek bizonyos fordítói rutint kívánnak, és a kezdő fordítók nem mindig végzik el öket. A pragmatikai explicitáció oka a forrásnyelvi és a célnyelvi olvasók háttérismereteinek különbsége. A fordításspecifikus explicitáció nem magyarázható a nyelv rendszerbeli, a nyelvhasználati vagy a kulturális különbségekkel, hanem a fordítás természetében rejlik.

Perego (2003) a professzionális fordítók filmfeliratozásának explicitációs vizsgálata során saját kategóriákat állított fel. Célja annak bizonyítása volt, hogy a fordítók a föként redukciós technikákat alkalmazó fordítástípusban, a feliratozásban is alkalmaznak explicitációval járó müveleteket.

\section{3.táblázat \\ Az explicitáció típusai a feliratozásban (Perego 2003)}

\begin{tabular}{|l|l|l|}
\hline \multicolumn{3}{|c|}{ Explicitáció } \\
\hline \multicolumn{1}{|c|}{ Kulturális } & \multicolumn{1}{|c|}{ Csatornaalapú } & \multicolumn{1}{c|}{ Redukcióalapú } \\
\hline 1.1 Betoldás & 2.1 Betoldás & 3.1 Betoldás \\
1.2 Konkretizálás & 2.2 Konkretizálás & 3.2 Konkretizálás \\
\hline
\end{tabular}

A kulturális explicitáció oka a forrásnyelvi és a célnyelvi kultúra közötti különbség. Csatornaalapú vagy interszemiotikus explicitáció akkor következhet be, ha váltás történik a szemiotikus csatornák között, pl. a vizuális non-verbális csatornáról a vizuális verbális csatornára. Redukcióalapú explicitáció akkor következhet be, ha a forrásnyelvi szöveget csökkenteni kell, hogy a megadott feliratdobozba beférjen. Ezzel nemcsak információveszteség, hanem információtöbblet is keletkezhet, mivel a kihagyott részek általában nem jelentősek, míg a csökkentés miatti betoldások alapvető fontosságúak a történet folytatásában.

Becher (2010a, 2010b) a Klaudy-féle tipológiát alkalmazta angolról németre és németről angolra fordított szövegek elemzése során és a kategóriák számának csökkentése mellett érvel. A fordításspecifikus explicitációt kivenné a tipológiából, de további kutatásokra ösztönzi a fordítástudománnyal foglalkozókat a fordítási aszimmetria területén (Klaudy 2001a, 2001b, 2009b).

A relevancielméleti megközelítés alapján De Metsenaere és Vandepitte (2017) csak két kategóriát javasol: a nyelvi rendszeren alapuló kategóriát (language systematic category) és a pragmatikai kategóriát (pragmatic category). A nyelvi rendszeren alapuló kategóriába tartozik a Klaudy-féle tipológiából a kötelező (obligatory) explicitáció, míg a pragmatikai kategóriába a fakultatív (optional) és pragmatikai (pragmatic) explicitáció tartozik. Habár a szerzők szerint a két kategória nem választható szét egyértelmüen egymástól, az első kategóriába mégis inkább azok az explicitációs és implicitációs jelenségek tartoznak, melyeket a nyelvi rendszerek közötti különbségek okoznak, míg a második kategóriába azok a jelenségek, melyeket ettől eltérő okok váltanak ki. 
De Metsenaere és Vandepitte (2017) egyértelmüen különbséget tesz explicitáció és explicitség között is. Explicitációról (explicitation) akkor beszélhetünk, ha a célnyelvi szöveget a forrásnyelvi szöveggel hasonlítjuk össze (ezt Chesterman (2004) F-univerzálénak hívta), mivel ekkor tudjuk vizsgálni a fordítás folyamata közben végbemenő jelenségeket. Ha a célnyelvre fordított szöveget azonban eredeti célnyelven írt szövegekkel hasonlítjuk össze, akkor fordítás valójában nem történik, így csak a szövegekben megfigyelhető explicitségi szint változását tudjuk vizsgálni, azaz komparatív explicitségröl (comparative explicitness) tudunk beszélni (ezt korábban Chesterman (2004) C-univerzálénak hívta).

Az explicitációkutatás tehát folyamatos változáson megy keresztül. Jelenleg a kognitív elméleti alapokon nyugvó relevanciaelméleti megközelítés egyértelmü különbséget tesz explicitáció és explicitség között, az egyiket a fordítás folyamatára, a másikat a fordítás eredményére vonatkoztatva. Az explicitáció tipologizálására pedig két fő kategóriát javasol: a kötelező explicitációt tartalmazó nyelvi rendszeren alapuló kategóriát, és a fakultatív explicitációt tartalmazó pragmatikai kategóriát.

\subsection{Az aszimmetria hipotézis}

A fordítási aszimmetria fogalmát Klaudy (2001a, 2001b) vezette be. A fordítási aszimmetria kétirányú fordításoknál figyelhető meg, tehát arra ösztönzi a fordítástudományi kutatásokat, hogy ne csak egyik nyelvről a másikra történő fordításokat elemezzen, hanem az így kapott eredményeket összehasonlítsa a másik nyelvi irányba történő fordítások során kapott eredményekkel. A fordítási aszimmetria célja, hogy a fordított nyelvre jellemző tulajdonságokat indirekt módon is vizsgálja, hiszen ha egy jelenség a fordítás egészére jellemző, akkor mindkét nyelvi irányban használatos lesz.

Az aszimmetria hipotézis Blum-Kulka explicitációs hipotézisének továbbgondolásából született. Az aszimmetria hipotézis szerint ,az explicitáció és implicitáció nem szimmetrikus müveletek, mivel a fordítók - ha van választási lehetőségük - előnyben részesítik és gyakrabban alkalmazzák a konkretizálás, felbontás és betoldás müveletét mint a generalizálás, összevonás és kihagyás műveletét". Az aszimmetria hipotézis tehát az átváltási müveletek alkalmazása során vizsgálja a müveleti szimmetriát illetve aszimmetriát.

A műveletei aszimmetria két módon vizsgálható: független és nem független kétirányú összehasonlító elemzéssel. Az első esetben adott nyelvpár esetén mindkét nyelvi irányban vizsgáljuk az átváltási müveleteket egymással fordítási kapcsolatban nem álló, de amúgy a lehető legtöbb paraméterben (müfaj, szövegtípus, kor, hely) hasonló szövegcsoporton. A második esetben olyan fordításokat vizsgálunk mindkét nyelvi irányban, melyek egymás fordításai, azaz visszafordítások.

Mindkét vizsgálati módszert alkalmazták már hazai és nemzetközi kutatásokban is. Az első vizsgálati típus hazai kutatására példa Klaudy és Károly (2005) kutatása, akik két magyarról angolra (Mikszáth Szent Péter esernyője, Kosztolányi 
Édes Anna) és egy angolról magyarra fordított regény (Orwell 1984) vizsgálata során megállapították, hogy a fordítók mindkét irányban az explicitebb formákat előnyben részesítik az implicitebb formáknál. További kutatásokat sürgetnek azonban nagyobb korpuszon és különböző explicitációval járó műveleteken az aszimmetria hipotézis alátámasztására. A nemzetközi kutatásokra számos példát hoz fel Klaudy (2014) a fordítási aszimmetria vizsgálatáról szóló cikkében. Ezek a kutatások nagyrészt igazolják az aszimmetria hipotézist, de megállapítják, hogy a nyelvi rendszer különbségéből fakadó explicitációt érdemes lenne kihagyni a vizsgálatokból, mivel torzíthatja az eredményeket.

A visszafordításban Makkos és Robin (2011) végzett többek között kutatásokat. Vizsgálatuk igazolta az aszimmetria hipotézist, mivel az explicitáció és az implicitáció nem bizonyult minden esetben szimmetrikus müveletnek. A visszafordítás során arra az érdekes eredményre jutottak, hogy a implicitációs müveletek száma egyenes arányban növekedett a fordítói kompetenciával, azaz minél tapasztaltabb volt a fordító, annál szabadabban hagyta ki a redundánsnak ítélt információt a fordított szövegböl. Kutatásuk eredményeként megfogalmazták az explicit telítettségről szóló hipotézist, „miszerint amikor a fordítandó szöveg explicitsége eléri a kontextus által behatárolt információs telítettségi szintet, az explicitációs dinamika a fordítás során csökken, és az implicitáció kerülhet túlsúlyba". Az explicit telítettség hipotézisének vizsgálata érdekes kutatási terület lehet a feltehetően inkább implicitációval járó feliratozás során keletkezett szövegekben.

Az aszimmetria hipotézis szorosan kapcsolódik az explicitációval illetve implicitációval járó fordítói megoldások vizsgálatához, így ezt a hipotézist a feltehetően több implicitációval mint explicitációval járó feliratozás során fontosnak és érdekesnek tartom kutatni.

\section{Esettanulmány}

Az explicitáció és implicitáció kontrasztív szövegnyelvészeti kutatásának hagyományait betartva korábban végeztem egy esettanulmányt (Malaczkov 2018a, 2018b), melynek célja az explicitációval és implicitációval járó fakultatív átváltási müveletek összehasonlítása volt a feliratokban. A kutatás Klaudy Kinga (1999a: 15) besorolása alapján vizsgálta az explicitáció kategóriájába tartozó lexikai és grammatikai konkretizálást, felbontást és betoldást, valamint az implicitáció kategóriájába tartozó lexikai és grammatikai generalizálást, összevonást és kihagyást. Ezzel összhangban a kutatás három kérdés megválaszolását tűzte ki céljául: 1 . Mi az explicitáció és implicitáció aránya az angolról magyarra fordított TED feliratokban? 2. Mely explicitációs illetve implicitációs típusok a leggyakoribbak a fordított feliratokban? 3. Mivel indokolható a leggyakoribb típus megjelenése?

Az adatok alapján az implicitációs műveletek aránya mindegyik vizsgált szöveg esetében meghaladta az explicitációs müveletek arányát. Átlagosan az implicitációs müveletek explicitációs műveletekhez viszonyított aránya 41,23\%. A mi- 
nikorpuszos kutatásból tehát az a tendencia figyelhető meg, hogy az ismeretterjesztő előadások feliratozása során a fordítók által alkalmazott implicitációs megoldások meghaladták az explicitációval járó átváltási müveleteket. Ennek alapján érdemes lenne felállítani az implicitációs hipotézist, mely szerint feliratozás során az implicitációval járó fordítói megoldások meghaladják az explicitációval járó megoldásokat.

Az önkéntes fordítók által leggyakrabban használt fordítási megoldás a lexikai implicitáció (generalizálás, összevonás, kihagyás) volt, ezen belül is a lexikai kihagyás. A lexikai kihagyás négy fő típusát mutattam ki az adatok alapján:

(1) szóbeliségre jellemző mondatkezdő kohéziós elemek kihagyása,

(2) tartalmi funkciót nem hordozó lexikai elemek kihagyása,

(3) szóismétlő elemek kihagyása és

(4) paralingvisztikai elemek kihagyása.

A további kutatások azonban rávilágítottak, hogy az AVT fó jellegzetessége, a multimodalitás miatt nem használható önmagában a kontrasztív szövegelemzés mint vizsgálati módszer, hiszen nem veszi figyelembe sem a más csatornán érkező audiovizuális elemeket, sem a technikai korlátozások miatti nyelvi korlátozást. A hiányzó láncszem a kutatásban a Kovačič (1994), Heltai (2008), Murtisari (2011, 2013) De Metsenaere és Vandepitte (2017) valamint Braun (2018) által is javasolt relevanciaelméleti megközelítés.

\section{A tervezett kutatás leírása}

További kutatásom célja az explicitáció jelenségének feltárása és rendszerbe foglalása az audiovizuális fordításon belül. A vizsgálatom az AVF típusai közül a feliratozásra korlátozódik. Az audiovizuális szövegek és maga az audiovizuális fordítási mód olyan jellegzetességekkel rendelkeznek, melyek a hagyományos, írott szövegek kutatásától eltérő megközelítést igényelnek. Az audiovizuális szövegek egyik fő jellemzője a multimodalitás, ezért vizsgálatuk nem korlátozódhat a hagyományos szövegnyelvészeti kutatásokra. A multimodalitás mellett a feliratozás másik fó jellegzetessége a technikai korlátozottság és a befogadói elvárásoknak való megfelelés, melyek hatással lehetnek az alkalmazott explicitációs és implicitációs müveletekre.

A kutatás további célja olyan elméleti és módszertani keretrendszer felállítása, mellyel az explicitáció jelenségét más típusú audiovizuális szövegeknél vagy eltérö fordítói csoportnál is vizsgálni lehet. Célom, hogy az eddigi kontrasztív szövegnyelvészeti kutatásokat a relevanciaelmélettel kombinálva megfelelő elméleti és módszertani kereteket biztosítsak az audiovizuális szövegek kutatásához. Ez lehetővé teszi a kutatások folytatását vagy megismétlését más audiovizuális anyagoknál is, valamint a kutatási eredmények jövőbeni összehasonlíthatóságát. 
Az explicitáció és implicitáció jelenségét angol-magyar és magyar-angol irányú TED előadások felirataiban vizsgálom az aszimmetria hipotézis segítségével. Az explicitáció kétirányú vizsgálata alátámaszthatja vagy éppen cáfolhatja az explicitáció mint forditási univerzálé létét. A feliratozást önkéntes fordítók végzik, így készülő disszertációmban az önkéntes fordítók munkáján belül a közösségi közreműködésen alapuló feliratozást (Jiménez-Crespo 2017) vizsgálom.

A kutatásom célja összességében az explicitáció jelenségének vizsgálata az aszimmetria hipotézis segítségével az audiovizuális fordításban, mégpedig az önkéntes TED feliratozók angol-magyar és magyar-angol nyelvi irányú munkájában.

\subsection{A korpusz}

A kutatási korpuszt az ELTE BTK Fordítástudományi Doktori Program keretei között létrehozott Pannónia Korpusz adja (Robin et al 2016, Robin és Szegh 2018). A Pannónia korpusz a magyar fordított szövegek kutatására kifejlesztett, több millió szövegszót tartalmazó fordítási korpusz. A multimodális korpusz fordított, tolmácsolt, audiovizuális, szak- és irodalmi szövegeket egyaránt magában foglal.

A Pannónia Korpusz audiovizuális alkorpusza tartalmazza a TED előadások eredeti nyelvű átiratát és az önkéntes fordítók által készített feliratokat is. A kutatott TED előadások videóanyaga ingyenes és könnyen elérhető formában megtalálható az interneten a TED honlapján. A nyelvészeti alapú AVF kutatásokhoz megfelelö kutatási anyagot szolgáltatnak a TED feliratok, mivel számos nyelvre fordították le az általában eredeti angol előadásokat, és ezek a publikált fordítások nyilvánosan elérhetők az online felületen. A multilingvális fordítások például a diskurzusjelölők kutatásához nyújtanak megfelelő kutatási anyagot (Furkó et al 2019).

Az önkéntes fordításból adódóan az angolról magyarra, azaz az anyanyelvre fordított TED szövegek száma jelentős, azonban a magyarról angolra, azaz B nyelvre fordított szövegek száma már jóval kevesebb. Mivel az alacsonyabb számú angolra fordított szöveg behatárolja a kutatási korpusz méretét, ezért 10-10 angolmagyar illetve magyar-angol nyelvi irányú feliratozott előadást vizsgálok a kiindulási korpuszban.

\subsection{Problémafelvetés}

Az explicitáció és explicitség vizsgálatával számos kutató foglalkozott már, de audiovizuális szövegeken ez a kutatás még nem jelentős. Ennek számos oka lehet. Egyrészt magyarázható az explicitáció és explicitség nem egységes definíciójával, mely megnehezíti az azonos kutatási keretek felállítását. Ugyanígy magyarázható az AVF jellegzetességeivel, azaz a multimodalitás és a technikai korlátok miatt a redukciós technikák inkább jelen vannak a nyelvi közvetítés során, mint az explicitációval járó müveletek.

A relevanciaelméleti kutatások különbséget tesznek az explicitációval és betoldással, illetve az implicitációval és kihagyással járó müveletek között. Érdekes 
megvizsgálni, hogy vajon az audiovizuális szövegekben milyen kapcsolat áll fenn ezen müveletek között. Vajon mennyiben explicitebb vagy éppen implicitebb a fordított audiovizuális szöveg az eredeti nyelvü szöveghez képest? Vajon milyen explicitációval vagy implicitációval járó müveletek tárhatók fel? Vajon vizsgálhatók-e ezek a mủveletek nagyméretủ gépi korpuszon? A kutatásom célja ezen kérdések megválaszolása.

Díaz-Cintas (2004: 51) az audiovizuális anyagokon végzett kutatásokkal kapcsolatban megjegyzi, hogy ,azon fordítási koncepciók és elméletek, amelyeket a fordítástudományi kutatások során eddig alkalmaztak, nem müködnek az AVF keretei között. Emiatt a kutatók inkább a kevésbé összetett empirikus jelenségeket vizsgálják, ahelyett, hogy megbonyolítanák a kutatói életüket meglévő elméletek megújításával vagy új elméletek kidolgozásával, melyek már az AVF jellegzetességeit is befogadnák" (Ford. M.Sz.). A kutatásom célja így épp az, hogy az eddigi fordítástudományi kutatásokat továbbvigyem, és olyan elméleti és módszertani kereteket találjak, melyek között az audiovizuális szövegeken is kutatható a korábban már számos szövegtípuson vizsgált jelenség.

\subsection{Kutatási kérdések és hipotézisek}

Az explicitáció és az audiovizuális fordítás szakirodalmának átnézése valamint saját kutatási célom alapján a következő kutatási kérdéseket fogalmazom meg a fent említett fö kutatási területen belül:

1. Milyen explicitációval és implicitációval illetve betoldással és kihagyással járó müveleteket végeznek az önkéntes feliratozók?

2. Mi az explicitáció és implicitáció aránya a feliratokban?

3. Mivel magyarázható az explicitáció és implicitáció valamint a betoldás és kihagyás jelensége és esetlegesen eltérő megoszlása?

4. Igazolható-e az aszimmetria hipotézis a vizsgált korpuszban?

5. Hogyan változik a fordított feliratok explicitségi szintje az eredeti nyelvü feliratokhoz képest?

Az eddigi kutatások áttekintése és saját feliratozási tapasztalatom alapján a következő feltételezéseket állítom fel a kutatási kérdéseimre:

1. Mindkét nyelvi irányban a generalizálás és az összevonás, azaz az implicitáció és a kihagyás lesz a legjellemzőbb müvelet egyrészt a technikai korlátok másrészt az olvasói elvárások miatt.

2. Az implicitációval és kihagyással járó müveletek gyakrabban fordulnak elő a feliratozás során, mint az explicitációval vagy betoldással járó müveletek, melynek oka a technikai korlátozottság. Az explicitáció-implicitáció nem arányos eloszlását egyrészt a felirat mint szövegalkotás korlátozottsága, 
másrészt a szóbeli regiszter írásbeli regiszterre történő átváltása okozhatja a szóbeli elemek kihagyása miatt.

3. A relevanciaelmélet alapján a fordítók az optimális relevancia elérésére törekednek, így ennek megfelelőn fordulnak explicitációs vagy implicitációs megoldásokhoz. Habár a technikai korlátok az implicitáció és kihagyás müveletét igényelhetik a feliratozásban, a korlátok önmagában nem tudnak magyarázatot adni arra, hogy mi motiválhatta a fordítókat adott átfogalmazásra (reformulation). Erre a választ a relevanciaelmélet adja meg.

4. Véleményem szerint az aszimmetria hipotézis igazolható lesz a vizsgált korpuszban, mivel mindkét irányban inkább az implicitációval és kihagyással járó müveletek aránya lesz nagyobb.

5. A fordított feliratok kevésbé lesznek explicitek a technikai korlátok megléte miatt, mely a nyelvi kifejtés lehetősége ellen hat.

\subsection{A kutatás menete}

A tervezett kutatás három fö részre oszlik majd: egy kérdőíves kutatásra az önkéntes feliratozók körében, az explicitációval és implicitációval járó jelenségek tipologizálására a feliratozásban, illetve az explicitáció és implicitáció kvalitatív és kvantitatív vizsgálatára.

A kérdőíves felmérés célja az önkéntes fordítók motivációjának és profiljának feltérképezése. A magyar TED fordítók csoportja jelenleg kb. 300 főből áll. A csoportnak kiküldött kérdőív célja az önkéntes fordítók profiljának felállítása a demográfiai adatok alapján, attitüdvizsgálat az önkénteskedés mögötti motivációs tényezők vizsgálatára, a feliratozás során megjelenő nyelvészeti problémáik feltárása és összegyűjtése, a minőségről alkotott fogalmuk és a feliratok minőségét biztosító tényezők vizsgálata.

A kvalitatív kutatás a fordítás folyamatát vizsgálja majd az explicitációval és implicitációval járó müveletek feltárása érdekében, valamint azokat az okokat keresi, melyek ezen stratégiák alkalmazásához vezettek.

A kvantitatív kutatás a fordítás eredményét vizsgálja majd, és az explicitségi szint változását próbálja kimutatni a fordított szövegekben nagymintás gépi korpuszalapú vizsgálatok segítségével. A korpuszalapú kutatások fontosságára számos kutató hívta már fel a figyelmet (Baker 1996, Laviosa 1998, Olohan 2004, Klaudy 2005), hiszen ezek a vizsgálatok új információt szolgáltathatnak a fordított szövegek jellegzetes tulajdonságainak feltárásához.

\section{7. Összefoglalás}

A kutatásomat egyrészt a TED elöadások és azok feliratozása ösztönözte, valamint a fordítástudományban régóta kutatott explicitáció jelenségének egy új fordítástípusban történő vizsgálata. A kezdeti kontrasztív szövegnyelvészeti alapokon nyug- 
vó kutatásaim igazolták azt a sejtésemet, hogy az implicitáció és a kihagyás mint fordítási stratégia talán nagyobb számban jelenik meg a fordított feliratozás során, mint az explicitáció és a betoldás. Ez az eredmény további kutatásokra inspirált az explicitációs hipotézis és ezzel összhangban az aszimmetria hipotézis igazolására. A kezdeti kutatások azt is megmutatták, hogy a pusztán kontrasztív szövegnyelvészeti kutatások az adott fordítástípusnál nem alkalmazhatók, hiszen éppen az AVF-re jellemző tulajdonságokat nem veszi figyelembe a vizsgálat során. Ezért a kommunikációelméleten belül a relevanciaelméletet hívtam segítségül, mely már lehetőséget teremt az audiovizuális szövegen belül is az explicitáció és implicitáció vizsgálatára. A kutatás végső célja, hogy egy újonnan megjelent fordítástípuson vizsgálja a fordítástudomány központi kérdéseit, és szükség esetén módosítson az eddigi elméleten a 21. század fordítási kihívásait szem előtt tartva.

\section{Irodalom}

Anderson, Ch. 2016. Így készülnek a TED elöadások. Budapest: HVG Kiadó Zrt.

Antonini, R., Cirillo, L., Rossato, L., Torresi, I. 2017. Introducing NPIT studies. In: Antonini, R. et al. (eds) Non-professional Interpreting and Translation. State of the art and future of an emerging field of research. Amsterdam/Philadelphia: John Benjamins. https://doi.org/10.1075/bt1.129.01ant

Baker, M. 1993. Corpus Linguistics and Translation Studies - Implications and Applications. In: Baker M., Francis G., Tognini-Bonelli E. (eds) Text and Technology: In Honour of John Sinclair. John Benjamins Publishing Company. 233-250.

Baker, M. 1995. Corpora in Translation Studies: An Overview and Some Suggestions for Future Research. Target Vol. 7. No. 2. 223-243. (Reprinted in Kim, K. H., Zhu, Y. (eds) 2019. Researching Translation in the Age of Technology and Global Conflict. Series: Key Thinkers in Translation. Routledge. 25-43. https://doi.org/10.4324/9780429024221-3 )

Baker, M. 1996. Corpus-based translation studies: The challenges that lie ahead. In: H. Somers (ed.) Terminology, LSP and Translation: Studies in language engineering in honour of Juan C. Sager. Amsterdam/ Philadelphia: John Benjamins. 175-186. (Reprinted in Kim, K. H., Zhu, Y. (eds) 2019. Researching Translation in the Age of Technology and Global Conflict. Series: Key Thinkers in Translation. Routledge. 44-54. https://doi.org/10.4324/9780429024221-4 )

Baker, M. (ed.) 1998. Routledge Encyclopedia of Translation Studies. London: Routledge. (Reprinted in 2003 https://doi.org/10.4324/9780203359792 )

Becher, V. 2010a. Abandoning the Notion of "Translation-inherent" Explicitation. Against a Dogma of Translation Studies. Across Languages and Cultures Vol. 11. No. 1. 1-28. https://doi.org/10.1556/acr.11.2010.1.1

Becher, V. 2010b. Towards a More Rigorous Treatment of the Explicitation Hypothesis in Translation Studies. trans-kom Vol. 3. No. 1. 1-25. http://www.trans-kom.eu/ bd03nr01/trans-kom_03_01_01_Becher_Explicitation.20100531.pdf Letölve: 2017. szeptember 23 . 
Blum-Kulka, S. 1986. Shifts of Cohesion and Coherence in Translation. In: House, J., Blum-Kulka, S. (eds) Interlingual and Intercultural Communication: Discourse and Cognition in Translation and Second Language Acquisition Studies. Tübingen: Gunter Narr. 17-35.

Bogucki, Ł. 2010. The demise of voice-over? Audiovisual translation in Poland in the 21st century. In: Lewandowska-Tomaszcyk, B., Thelen, M. (eds) Meaning in translation. Frankfurt am Main: Peter Lang. 415-424. Book DOI: https://doi.org/10.3726/978-3653-00940-8

Braun, S. 2018. The importance of being relevant? A cognitive-pragmatic framework for conceptualising audiovisual translation. In: Gambier, Y., Ramos Pinto, S. (eds) Audiovisual translation. Theoretical and methodological challenges. Amsterdam/Philadelphia: John Benjamins. 121-132. https://doi.org/10.1075/bct.95.10bra

Chaume, F. 2002. Models of Research in Audiovisual Translation. Babel Vol. 48. No. 1. 1-13. https://doi.org/10.1075/babel.48.1.01cha

Chaume, F. 2013. The turn of audiovisual translation. New audiences and new technologies. Translation Spaces No. 2. 105-123. https://doi.org/10.1075/ts.2.06cha

Chaume, F. 2018. An overview of audiovisual translation: Four methodological turns in a mature discipline. Journal of Audiovisual Translation Vol. 1. No. 1. 40-63.

Chesterman, A. 2004. Beyond the Particular. In Mauranen, A., Kujamäki, P. (eds) Translation Universals. Do They Exist? Amsterdam/Philadelphia: John Benjamins Publishing. 33-50 https://doi.org/10.1075/btl.48.04che

De Metsenaere, H., Vandepitte, S. 2017. Towards a Theoretical Foundation for Explicitation and Implicitation. trans-kom Vol. 10. No. 3. 385-419.

Di Giovanni, E., Gambier, Y. (eds) 2018. Reception Studies and Audiovisual Translation. Amsterdam / Philadelphia: John Benjamins. https://doi.org/10.1075/btl.141

Díaz-Cintas, J. 2004. Subtitling: the long journey to academic acknowledgment. The Journal of Specialised Translation No. 1. 50-68.

Díaz-Cintas, J. 2018. 'Subtitling's a carnival': New practices in cyberspace. The Journal of Specialised Translation No. 30. 127-149.

Dollerup, C. 1974. On subtitles in television programmes. Babel Vol. 20. No. 4. 197-202. https://doi.org/10.1075/babel.20.4.05dol

Furkó, P. et al. 2019. Functions and translations of discourse markers in TED Talks: A parallel corpus study of underspecification in five languages. Journal of Pragmatics No. 142. 139-155. https://doi.org/10.1016/j.pragma.2019.01.012

Gambier, Y. 2012. The position of audiovisual translation studies. In: Millán, C., Bartrina, F. (eds) The Routledge Handbook of Translation Studies. London: Routledge. 45-59. https://doi.org/10.4324/9780203102893.ch3

Glózer R. 2016. Részvétel és kollaboráció az új médiában. Replika 5. szám. 131-150.

Gottlieb, H. 1992. Subtitling - A New University Discipline. In: Dollerup, C., Loddegaard, A. (eds) Teaching Translation and Interpreting. Amsterdam/Philadelphia: John Benjamins.161-170. https://doi.org/10.1075/z.56.26got

Gottlieb, H. 1998. Subtitling. In Baker, M. (ed.) Routledge Encyclopedia of Translation Studies. London: Routledge. 244-248. (Book reprinted in $2003 \mathrm{https} / /$ doi. org/10.4324/9780203359792 )

Hatim, B., Mason, I. 1997. The Translator as Communicator. London: Routledge. (Reprinted in 2005 https://doi.org/10.4324/9780203992722 ) 
Heltai Pál. 2005. Explicitation, Redundancy, Ellipsis and Translation. In Károly Krisztina, Fóris Ágota (eds) New Trends in Translation Studies. Budapest: Akadémiai Kiadó. 45-74

Heltai P. 2008. The performance of relevance theory in translation studies. In: Wałaszewska, E., Kisielewska-Krysiuk, M., Korzeniowska, A., Grzegorzewska. M. (eds) Relevant worlds: Current perspectives on language, translation and relevance theory. Newcastle: Cambridge Scholars Publishing. 156-170.

Heltai P. 2014. Mitöl forditás a forditás? Budapest: Eötvös József Könyvkiadó.

Holmes, J. 1972. The Name and Nature of Translation Studies. Unpublished manuscript. AAPTS Series of The Translation Studies Section, Department of General Literary Studies, Amsterdam. Reprinted in: Holmes, J. 1988. Translated!. Amsterdam: Rodopi. $67-80$.

Horváth I. 2015. Önkéntes fordítás és tolmácsolás. In Horváth Ildikó (szerk.) A modern forditó és tolmács. Budapest: ELTE Eötvös Kiadó. 121-131.

Jiménez-Crespo, M. A. 2017. Crowdsourcing and Online Collaborative Translations: Expanding the Limits of Translation Studies. Amsterdam / Philadelphia: John Benjamins. https://doi.org/10.1075/btl.131

Király G. 2019. Részvétel és tanulás. A részvételi rendszermodellezés mint tanulási környezet. Budapest: Budapesti Gazdasági Egyetem. https://doi.org/10.29180/reszveteles-tanulas.2019

Klaudy, K. 1993. On Explicitation Hypothesis. In: Kinga Klaudy and János Kohn (eds) Transferre necesse est . . Current Issues of Translation Theory. In honour of Gyorgy Rado on his 80th birthday, Szombathely: Dániel Berzsenyi College. 69-79.

Klaudy K. 1999a. Az explicitációs hipotézisről. Forditástudomány 1. évf. 2. szám. 5-22. Klaudy K. 1999b. Bevezetés a forditás elméletébe. Budapest: Scholastica. (Reprinted in 2018 https://doi.org/10.1556/9789634541936 )

Klaudy K. 2001a. Az aszimmetria hipotézis. In: Bartha M. (szerk.) A X. Magyar Alkalmazott Nyelvészeti Konferencia elöadásai. Székesfehérvár: KJF. 371-378.

Klaudy, K. 2001b. The Asymmetry Hypothesis. Testing the Asymmetric Relationship between Explicitations and Implicitations. Conference presentation. 3rd International EST Conference. Copenhagen, Denmark. PPT downloadable from: https://www.researchgate.net/publication/277326602 The Asymmetry_Hypothesis_Testing the Asymmetric Relationship between Explicitations and Implicitations Retrieved: 4 March 2019.

Klaudy, K. 2003. Languages in translation. Lectures on the theory, teaching and practice of translation. Budapest: Scholastica.

Klaudy K. 2005. Párhuzamos korpuszok felhasználása a fordításkutatásban. In: Lanstyák István és Vančoné Kremmer Ildikó (szerk.). Nyelvészetröl változatosan. Segédkönyvek egyetemisták és a nyelvészet iránt érdeklödök számára. Dunaszerdahely: Gramma Nyelvi Iroda. 153-185.

Klaudy, K. 2009a. Explicitation. In: Baker, M. Saldanha, G. (eds) Routledge Encyclopedia of Translation Studies. London: Routledge. 104-109. (Book DOI: https://doi. org/10.4324/9780203872062 )

Klaudy, K. 2009b. The Asymmetry Hypothesis in Translation Research. In: Dimitriu, R., Shlesinger, M. (eds) Translators and Their Readers. In Homage to Eugene A. Nida. Brussels: Lés Éditions du Hazard. 283-303. 
Klaudy K. 2014. Újabb kutatások az aszimmetria hipotézis bizonyítására. In: Bárdosi V. (szerk.) Szövegalkotó gyakorlatok, nyelvteremtö praktikák. Budapest: Tinta Könyvkiadó. 113-121.

Klaudy, K., Károly, K. 2005. Implicitation in translation: empirical evidence for operational asymmetry in translation. Across Languages and Cultures Vol. 6. No. 1. 13-28. https://doi.org/10.1556/acr.6.2005.1.2

Kovačič, I. 1994. Relevance as a factor in subtitling reductions. In: Dollerup, C., Loddegaard, A. (eds) Teaching Translation and Interpreting 2. Amsterdam/Philadelphia: John Benjamins. 245-251. https://doi.org/10.1075/btl.5.35kov

Laviosa, S. 1998. The Corpus-based Approach: A New Paradigm in Translation Studies. Meta Vol. 43. No. 4. 473-659. https://doi.org/10.7202/003424ar

Makkos A., Robin E. 2011. Explicitáció és implicitáció a visszafordításban. Alkalmazott Nyelvtudomány 11. évf. 1-2. szám. 135-150

Malaczkov Sz. 2018a. Explicitáció és implicitáció aránya nem professzionális fordítók angol-magyar felirataiban. In: Bocz Zs., Besznyák R. (szerk.) Tudásmegosztás, értékközvetités, digitalizáció - trendek a szaknyelvoktatásban és -kutatásban. Budapest: SZOKOE. 41-52.

Malaczkov Sz. 2018b. Nem professzionális TED fordítók explicitációs stratégiái. In: Dombi J., Farkas J, Gúti E. (szerk.) Aszimmetrikus kommunikáció - aszimmetrikus viszonyok. Bicske: SZAK Kiadó. 565-585.

Mayoral, R., Kelly, D., Gallardo, N. 1988. Concept of Constrained Translation. Non-Linguistic Perspectives of Translation. Meta No. 33. No. 3. 356-367. https://doi. org/10.7202/003608ar

Murtisari, E. T. 2011. The uses of relevance theory for the study of explicitation (Unpublished doctoral dissertation). Melbourne: Monash University.

Murtisari, E. T. 2013. A relevance-based framework for explicitation and implicitation: An alternative typology. trans-kom Vol. 6. No. 2. 272-281.

Olohan, M. 2004. Introducing Corpora in Translation Studies: an Introduction. Routledge. https://doi.org/10.4324/9780203640005

Orero, P., Braun, S. 2010. Audio description with audio subtitling - an emergent modality of audiovisual localisation. Perspectives Vol. 18. No. 3. 173-188. https://doi.org/10.1 080/0907676x.2010.485687

Orrego-Carmona, D., Lee, Y. 2017. Non-Professional Subtitling. In: Orrego-Carmona, D., Lee, Y. (eds) Non-Professional Subtitling. Newcastle upon Tyne: Cambridge Scholars Publishing. 1-14.

Paksy E. 2016. Nem professzionális fordítás és fordítói önkép. In: Reményi A., Sárdi Cs., Tóth Zs. (szerk.) Távlatok a mai magyar alkalmazott nyelvészetben. Budapest: Tinta Könyvkiadó. 372-379.

Pápai V. 2001. Az explicitációs hipotézis vizsgálata angol-magyar és magyar-magyar párhuzamos korpuszok egybevetésével. Győr/Pécs: Pécsi Tudományegyetem. (Kiadatlan doktori disszertáció)

Pápai, V. 2004. Explicitation. A Universal of Translated Text? In Mauranen, A., Kujamäki, P. (eds) Translation Universals: Do They Exist? Amsterdam/Philadelphia: John Benjamins. 143-164. https://oi.org/10.1075/btl.48.12pap

Perego, E. 2003. Evidence of Explicitation in Subtitling: Towards a Categorisation. Across Languages and Cultures Vol. 4. No. 1. 63-88. https://doi.org/10.1556/acr.4.2003.1.4 
Pérez-González, L. 2009. Audiovisual Translation. In: Baker, M., Saldanha, G. (eds) Routledge Encyclopedia of Translation Studies. London: Routledge. 13-20. (Book DOI: https://doi.org/10.4324/9780203872062 )

Pérez-González, L. 2014. Audiovisual translation - Translation, methods and issues. London/New York: Routledge. https://doi.org/10.4324/9781315762975

Pérez-González, L. 2018. Rewiring the circuitry of audiovisual translation. In: PérezGonzález, L. (ed.) The Routledge Handbook of Audiovisual Translation. Abingdon: Routledge. 1-12. https://doi.org/10.4324/9781315717166-1

Pérez-González, L., Susam-Saraeva, Ş. 2012. Non-professionals Translating and Interpreting. The Translator Vol. 18. No. 2. 149-165. https://doi.org/10.1080/13556509.201 2.10799506

Reiss, K. 1971/2000. Translation Criticism. The Potentials and Limitations. (Ford.: Erroll F. Rhodes) London, New York: Routledge. (Reprinted in 2014 https://doi. org/10.4324/9781315760407)

Remael, A. 2010. Audiovisual translation. In: Gambier, Y., van Doorslaer, L. (eds) Handbook of Translation Studies. Vol. 1. Amsterdam / Philadelphia: John Benjamins. https://doi.org/10.1075/hts.1.aud1

Robin E., Dankó Sz., Götz A., Nagy A. L., Pataky É., Szegh, H., Zolczer, P. 2016. Fordítástudomány és korpuszkutatás: Bemutatkozik a Pannonia Korpusz. Fordítástudomány 18. évf. 2. szám. 5-26.

Robin E., Götz A., Pataky É., Szegh, H. 2017. Translation Studies and Corpus Linguistics: Introducing the Pannonia Corpus. Acta Universitatis Sapientiae, Philologica. Vol. 9. No. 3. 99-116. https://doi.org/10.1515/ausp-2017-0032

Robin E., Szegh H. 2018. A Pannónia Korpusz audiovizuális alkorpusza. In: Dróth J. (szerk.) Gépiesség és kreativitás a fordítási piacon és az oktatás különbözö szintjein. Budapest: KGRE, L'Harmattan Kiadó. 93-110.

Romero Fresco, P. 2012. Dubbing dialogues...naturally. A pragmatic approach to the translation of transition markers in dubbing. MonTI No. 4. 181-205. https://doi.org/10.6035/monti.2012.4.8

Szarkowska, A., Wasylczyk, P. 2018. Five things you wanted to know about audiovisual translation research, but were afraid to ask. Journal of Audiovisual Translation Vol. 1. No. 1. 8-25.

Shuttleworth, M., Cowie, M. 2014. Dictionary of Translation Studies. London: Routledge. 1st publ. 1997. https://doi.org/10.4324/9781315760490

Titford, C. 1982: Sub-titling - Constrained Translation. Lebende Sprachen Vol. 27. No. 3. $113-116$.

Zabalbeascoa, P. 2008. The nature of the audiovisual text and its parameters. In: DíazCintas, J. (ed.) The Didactics of Audiovisual Translation. Amsterdam / Philadelphia: John Benjamins. 21-38. https://doi.org/10.1075/btl.77.05zab

Zanotti, S., Ranzato, I. 2019. Intersections: audiovisual translation at the crossroads of disciplines. Perspectives Vol. 27. No. 2. 173-181. https://doi.org/10.1080/090767 6x.2018.1557715

Zimányi K. 2017. Az önkéntes fordítás problematikája és pedagógiai lehetöségei. In Kóbor M., Csikai Zs. (szerk.) IRÁNYTÜ az egyetemi forditóképzéshez. A kompetenciafejlesztés új fókuszai. Pécs: Kontraszt. 233-250. 